Georgia State University

ScholarWorks @ Georgia State University

World Languages and Cultures Faculty

Publications

Department of World Languages and Cultures

2013

\title{
Comprehension of Conversational Implicature in L2 Chinese
}

\author{
Naoko Taguchi \\ Carnegie Mellon University, taguchi@andrew.cmu.edu
}

Shuai Li

Georgia State University, sli12@gsu.edu

Yan Liu

Duke University, yl286@duke.edu

Follow this and additional works at: https://scholarworks.gsu.edu/mcl_facpub

Part of the Other Languages, Societies, and Cultures Commons

\section{Recommended Citation}

Taguchi, Naoko; Li, Shuai; and Liu, Yan, "Comprehension of Conversational Implicature in L2 Chinese" (2013). World Languages and Cultures Faculty Publications. 71.

https://scholarworks.gsu.edu/mcl_facpub/71

This Article is brought to you for free and open access by the Department of World Languages and Cultures at ScholarWorks @ Georgia State University. It has been accepted for inclusion in World Languages and Cultures Faculty Publications by an authorized administrator of ScholarWorks @ Georgia State University. For more information, please contact scholarworks@gsu.edu. 


\title{
Naoko Taguchi, Shuai Li and Feng Xiao Production of formulaic expressions in L2 Chinese: A developmental investigation in a study abroad context
}

\begin{abstract}
This study investigated the development of L2 Chinese formulaic competence in a study abroad context. Participants were 31 American students studying Chinese in a university in China (intermediate-level). They completed a computerized speaking test consisting of 24 formulae-use situations twice during their semester-long study abroad in China. The learners produced a formulaic expression according to each situation, and their production was evaluated on appropriateness (rated on a four-point scale by native speakers) and planning time. In addition, a survey was administered to gather information about the learners' perceived frequency of encounter with formulae-use situations. The learners showed significant gains on appropriateness and fluency. Reported frequency of encounter with target formulae-use situations did not correlate with the gains in formulae production, except for the learners with lower pretest score. Qualitative analysis revealed four patterns of change: (1) change toward target formulae, (2) change toward target-like slot-and-frame patterns, (3) change toward non-target formulae; and (4) stabilized non-target formulae use.
\end{abstract}

Keywords: L2 Chinese, formulaic competence, formulae production, interlanguage pragmatics, study abroad context, longitudinal

\footnotetext{
Naoko Taguchi: E-mail: taguchi@andrew.cmu.edu

Shuai Li: E-mail: sli12@gsu.edu

Feng Xiao: E-mail: fxiao@andrew.cmu.edu
}

\section{Introduction}

Formulaic language has received much empirical attention recently due to the recognition that L2 learners' use of it is an important aspect of their communicative competence (Schmitt 2004, Wray 2002). A growing number of studies have examined learners' formulaic language use, including: comprehension of idiomatic expressions (Kecskes 2003), routines (Roever 2005), conventional meaning (Taguchi 2008, 2009, 2011) and formulaic sequences (Conklin and Schmitt 2008, Ellis, Simpson-Vlach, and Maynard 2008, Jiang and Nekrasova 2007), and 
comprehension and production of conventional expressions (Bardovi-Harlig 2007, 2009a, 2009b). ${ }^{1}$

Although these studies have provided a relatively well-formed analysis of the nature and development of L2 formulaic competence, they have mostly focused on the comprehension of formulaic language in a cross-sectional design, and longitudinal studies that examined production of formulaic expressions, particularly in a language other than English, are seriously underrepresented in the field. Studies that investigated potential factors affecting formulaic development, such as exposure to the target language context, are also scarce. To fill these gaps, this study examines longitudinal development of production of formulaic language among American learners of L2 Chinese in a study abroad context. The study assesses the development of formulaic competence over a semester and the effect of reported frequency of exposure to formulae-use situations on this development.

\section{Background}

Formulaic language has been discussed under a variety of labels, including prefabricated routines (Hakuta 1974), formulas (Coulmas 1981), phrasal chunks (de Cook 1998), prefabs (Altenberg 1998), formulaic sequences (Schmitt 2004), situation-bound utterances (Kecskes 2003), chunks (Ellis 2003), and conventional expressions (Bardovi-Harlig 2009a, 2009b, Bardovi-Harlig et al. 2010). Some labels refer to invariable linguistic units, consisting of fixed forms and lexical sequences (e.g., "Have a good day."), while others, such as "slot-and-frame patterns" or "syntactic strings" (e.g., "I'm gonna" + verb), refer to variable and discontinuous units (Krashen and Scarcella 1978, Nattinger and DeCarrico 1992, Ellis 2003, Pawley and Syder 2000).

These literatures collectively summarize characteristics of formulaic language (e.g., Coulmas 1981, Kecskes 2000, Myles et al. 1999, Schmitt and Carter 2004, Wray 2002, Wood 2006). Formulaic expressions are: (1) multi-word sequences; (2) stored in mind as a holistic unit, (3) fixed syntactic strings that

\footnotetext{
1 Researchers use different terms to refer to a more or less similar concept of formulaic language (i.e., fixed or semi-fixed recurrent syntactic strings used to perform communicative functions in a given speech community), and there is no consensus as to which term best represents the nature of formulaic language. Because distinction among different terms and labels was not the purpose of this paper, we synonymously used the terms "formulaic language," "formulaic expressions," and "formulaic competence," as well as deviants of them (e.g., formulae, formulas), to refer to the target linguistic construct in this paper.
} 
may have slots to allow flexibility in use and occur frequently; (4) phonologically coherent (i.e., articulated without hesitation); (5) syntactically irregular (e.g., in the expression "beat around the bush," "bush" cannot be pluralized); (6) community-wide in use; and (7) tied to particular situations and speech events. $^{2}$

Based on these characteristics, in this paper, we define formulaic language and formulaic expressions as fixed or semi-fixed syntactic strings whose occurrence is closely bound to specific recurrent situations and communicative functions. Our definition corresponds to Bardovi-Harlig's (in press) definition that formulas are recurrent expressions used for specific pragmatic purposes. Formulas succinctly convey illocutionary force based on the tacit agreements on their form, meaning, and use among members of a speech community in dealing with day-to-day situations.

A growing number of SLA studies have examined L2 learners' ability to comprehend and produce formulaic expressions, or namely formulaic competence (e.g., Schmitt 2004, Wray 2002). This interest stems from an understanding that mastery of a new language requires learners to become sensitive to native speakers' preferences of certain fixed/semi-fixed word sequences over other plausible expressions (Pawley and Syder 1983, Wray 2000). ${ }^{3}$ The ability to select common expressions from less common ones, an ability Pawley and Syder call "native-like selection," is an important indicator of second language development. Below we will review relevant research that examines the development of formulaic competence among L2 learners. Studies reviewed here are largely from L2 English literature, because, to our knowledge, there are no Chinese studies on L2 formulaic language available to date.

\subsection{L2 formulaic competence in comprehension and production}

Adult L2 learners' knowledge and use of formulaic expressions have been examined in a variety of studies. Some are observational studies that examined

2 We acknowledge that these characteristics were largely drawn from English-based literatures and that whether or not they all apply to Chinese formulaic language is an empirical question. Because the purpose of this paper was not establishing Chinese-specific criteria for formulaic language, we used these pre-established characteristics as general, universal characteristics of formulaic language.

3 We acknowledge the on-going debate in the field regarding the use of native speaker norms in the analysis of L2 competence (e.g., Byram 1997). 
patterns of learners' formulaic language use (e.g., Blum-Kulka and Olshtain 1986, House 1993, 1996, Schmidt and Frota 1986, Riley 1989, Thomas 1983, WindnerBassett 1984), while others are experimental studies that used construct-eliciting instruments to examine learners' knowledge of formulaic expressions (e.g., Bardovi-Harlig 2009a, 2009b, Ellis, Simpson-Vlach, and Maynard 2008, Jiang and Nekrasova 2007, Kecskes 2000, 2003, Roever 2005, Schmitt et al. 2004, Taguchi 2011, Warga 2005). One generalization gleaned from this bulk of literature is that learners often use formulae in an idiosyncratic manner due to their inadequate control of knowledge and negative transfer from L1. Even advanced learners exhibit non-target patterns, which account for a large number of usage errors.

Kecskes (2000) examined nonnative English speakers' ability to comprehend and produce situation-bound utterances (SBU) (i.e., prefabricated sentences and phrases associated with certain situations, such as "What's up"). Eighty-eight students with mixed L1s in the U.S.A. completed three written tasks assessing their knowledge of SBUs: (1) a discourse completion task (DCT) in which students produced SBUs, (2) a dialogue comprehension task which assessed students' understanding of SBUs, and (3) a problem-solving task in which students read a situation and produced an utterance for the situation. Results revealed students' difficulty in comprehension. Production data revealed students' idiosyncratic expressions (e.g., in response to "How are you doing?," saying "Pretty good. I am happy."). Even students who had spent more than two years in the U.S.A. were non-native-like in their selection of target forms, indicating that time spent in the target country does not automatically lead to native-like use of SBUs.

While Kecskes's findings revealed learners' difficulty with formulaic expressions in both comprehension and production, several studies revealed the relative ease of comprehension over production. In Schmidt et al.'s (2004) study, 94 learners of English of mixed L1s completed two tasks measuring their ability to produce and comprehend formulaic expressions over a few months. The production measure took the format of cloze test in which learners were given the initial letter(s) of each word and asked to fill in the missing words. The comprehension task took a multiple-choice format: the learners were asked to choose correct formulaic sequences to fill in the missing lines in a story. Results showed that the learners averaged a $24 \%$ gain in the production task and a $12 \%$ gain in the comprehension task. Small comprehension gain was explained by the ceiling effect: The learners were already competent in the comprehension of formulaic expressions at the beginning of the study.

Lending support to these findings, more recently, Bardovi-Harlig (2009a, 2009b) explored the relationship between comprehension and production of conventional expressions by using a comprehension task paired with a DCT. In her 
2009a study, 122 learners of English as a second language (ESL) in the U.S.A. (mixed L1s) completed a comprehension task in which they listened to 60 conventional expressions and rated their degree of familiarity with the expressions (from "never heard of it" to "I know the expression"). At the same time, they completed a 32-item production task in which they read situational descriptions and produced the expression that best fit the situation. Results showed that the learners were better on comprehension than on production. Proficiency (determined by course level) positively influenced both comprehension and production, although even advanced-level learners still fell short of native-speaker level production.

These findings suggest a potential modality effect. Compared with comprehension, production of formulaic expressions is more demanding because of a more fine-tuned syntactic/lexical analysis required in production. In comprehension, it is possible to infer overall meaning of a formulaic expression without precise linguistic analysis of it by relying on contextual cues, but in production, lexis and morpho-syntax must be exact and accurate so that the meaning encoded in the forms is understood correctly. Incorrect linguistic representation, as seen in wrong word order or word choice, may obscure meaning or lead to misunderstanding. For instance, when asking the time, people commonly say, "Do you have the time?" Without the article ("Do you have time?"), the sentence completely changes its meaning (asking whether one has time to spare). Hence, the degree of “native-like selection” (Pawlye and Syder 1983), an index of L2 formulaic competence, seems to reveal more in production than in comprehension because production data shows learners' choice of lexis and grammar more precisely. Formulaic competence entails the ability to select and produce exact strings of preferred forms to convey illocutionary force. Various indicators of interlanguage forms found in the previous literature, such as verbosity, word choice errors and grammatical mistakes, suggest that learners have difficulty in producing exact strings common in the speech community.

Because a majority of the existing studies has focused on the comprehension of formulaic expressions, and very few studies have examined the production of the expressions in a language other than English, the present study directly fills the gap by examining production of formulaic expressions among learners of L2 Chinese. Because formulaic expressions are, by definition, fixed or semi-fixed linguistic units, syntactic and lexical choices have to be exact for them to stand as formulae. Hence, an important question is to what extent L2 Chinese learners are able to produce formulaic expressions as holistic units with precise, target-like grammar and lexis, and whether their ability develops over time in an environment that presumably offers exposure to target formulaic expressions. This study addresses this question. 


\subsection{Effect of target language context on formulaic competence}

One trend observed in the previous literature on formulae is that most studies were conducted in the target language environment. With a few exceptions (e.g., House 1996), participants were recruited from the target community, involving immigrants, bilingual children, and international students enrolled in language programs or universities. This trend probably corresponds to the assumption that formulaic development is best observed in a place where formulaic expressions are most salient. The ubiquitous nature of formulaic language (i.e., communitywide in use, tied to ordinary situations and speech events) suggests that formulaic language permeates our everyday communication, assisting our social participation and daily functioning. ${ }^{4}$ Given these characteristics, it makes sense to examine formulaic development in a context where the target language is spoken because learners presumably have abundant exposure to the expressions preferred by native speakers. In the host environment, learners have opportunities to observe preferred response patterns in everyday conversations and practice them through routine participation in social events.

While the advantage of study abroad in formulaic competence makes intuitive sense, only a few studies to date have directly examined the effect of target language context in formulaic competence. Roever (2005), for instance, compared ESL learners in the U.S.A. and EFL learners in Germany on comprehension of routines. Twelve routine items tested comprehension of situational routines that were tied to specific situations and functional routines that were not situation-bound (e.g., "Excuse me, do you have the time?"). Results revealed a significant effect of the residence abroad experience on the comprehension of routines, but proficiency had no effect on comprehension.

Taguchi (2011), on the other hand, examined the effect of proficiency and study abroad experience in the comprehension of routines (formulaic expressions) and implicature (non-formulaic, non-literal utterances). Japanese college students studying English as a foreign language (EFL) were divided into three groups. Group 1 had lower proficiency and no study abroad experience. Group 2 and Group 3 had higher proficiency than Group 1 but differed in their study abroad experience: Group 2 had no study abroad experience, but Group 3 had at least one year of study abroad experience. They completed a listening test measuring their ability to comprehend routines and implicature. Group performance was compared for the comprehension accuracy scores and response times. There was a

4 As one reviewer mentioned, this function of formulaic language is reminiscent of metaphors. Interested readers can refer to Lakoff and Johnson (1980). 
significant proficiency effect on response times for both item types, but study abroad experience had no effect on response times. However, study abroad experience had effect on the accurate comprehension of routines. A limitation of Taguchi's study is that the effect of study abroad was examined only indirectly because the participants with study abroad experience were all returnees: They were not living in the host country at the time of data collection. In order to seek a more direct relationship between residence abroad and formulaic competence, studies that recruit participants while they are abroad are necessary.

In summary, these previous findings suggest that increased proficiency alone does not contribute to the knowledge and use of formulaic expressions, and additional target language input might help learners to move from idiosyncratic, interlanguage usage of formulae to more conventional, target-like usage. Unlike other aspects of language, formulaic language is closely tied with everyday colloquial language use and is learned through participation in real-life communicative events. This insight was supported by empirical data in Dornyei et al. (2004) who provided a conjoined analysis of learners' acquisition of formulaic language and the degree of learners' social network in the target community. Seven participants selected from the pool of 24 participants in Schmitt et al.'s (2004) study (cited in the previous section) were interviewed periodically. Data revealed that successful learning of formulaic expressions was strongly related to the learners' active involvement in the English-speaking community, suggesting that formulaic learning is to a large extent the function of the learners' sociocultural integration. Although the advantage of study abroad in formulaic development has some empirical support, more research is needed in this area to confirm the generalizability of the findings, particularly in the production of formulaic expressions (rather than comprehension) where research is considerably limited. In addition, following Dornyei et al.'s study, additional measures on learning context are necessary in order to gain insights into learners' actual experiences with formulaic language.

The effect of target language context in formulaic development can be examined in a variety of ways, such as comparing the performance of learners in study abroad and domestic instructional contexts (Roever 2005 and Taguchi 2011 cited above) or tracking the development in a host environment with in-depth qualitative data from observations and interviews. Another potentially useful method is to document the amount of target language contact. Previous studies have used a survey, diary, and log to examine the extent of language contact and its impact on language gains during study abroad in areas of oral fluency, reading, writing, listening, grammar, vocabulary acquisition, and pragmatics (Dewey 2004, Kinginger 2008, Pérez-Vidal and Juan-Garau 2009, Segalowitz and Freed 2004, Taguchi 2008). Some of these studies have used a survey called the "Language Contact 
Profile" (LCP) in order to document learners' amount of outside class contact with the target language (Freed et al. 2004). The survey asked learners to report how many days per week and how many hours per day they spent doing certain activities (e.g., interacting with native or fluent speakers of the target language). The product of these two numbers (i.e., the number of days per week and hours per day) gave an estimate of total time per week for each activity.

Because very few studies have analyzed the development of formulaic competence in relation to the amount of L2 exposure, more research is needed in this area. Surveys such as LCP could be adapted to gain more fine-tuned information about language contact specific to formulaic language. Considering that formulaic language consists of fixed or semi-fixed lexical strings tied to specific communicative situations, actual frequency of encounters of individual expressions, rather than exposure to target language input in general, could be a more precise measure of contact that learners have with formulaic language during study abroad. This is what we pursued in this study. In addition, most previous studies used a cross-sectional design to provide a snapshot description of learners' formulaic competence (but see Schmitt et al. 2004), and very few studies have addressed the development of formulaic competence longitudinally in relation to the factors that could facilitate this development. Our study fills these gaps in the literature through a longitudinal investigation into formulaic competence, in relation to learners' reported contact with formulaic expressions. Two research questions guided this study:

RQ1) Do L2 learners of Chinese make progress in their ability to produce formu-

laic expressions in a target-like manner during study abroad?

RQ2) Is there a relationship between the reported frequency of encounter of target formulaic expressions and gains in production of the expressions?

\section{Methodology}

\subsection{Participants}

The participants were 31 American college students (15 females and 16 males) enrolled in a fourteen-week study abroad program in Beijing, China. The participants aged between 19 to 25 years $(M=20.5)$. On average, the students had had 3.4 semesters of formal Chinese study (about three to five hours per week) before participating in this project. None had studied in a Chinesespeaking community before. While in China, all participants were enrolled in 
intermediate-level Chinese classes and received about nine hours of instruction per week. ${ }^{5}$

\subsection{Instrumentation: Creating formulae-use situations}

As formulaic expressions are often tied with specific language-use situations, it is important to create appropriate situations that can elicit target formulaic expressions. We took four steps to develop target formulae-use situations. First, we consulted a number of reference books in Chinese (e.g., tour guidebooks and manuals aimed at introducing routine Chinese expressions to international visitors $^{6}$ ) to select candidate formulae, that is, expressions that are commonly used in daily situations in China such as 去...怎么走 ? (Qù . . . zěn me zǒu? “How to get to ... ?”) 你打错了。(Nǐ dă cuò le. “You have dialed the wrong number.”). We also took field notes in China over a few months to gather candidate formulaic expressions as well as the situations in which those expressions were used. Second, based on the field notes and the expressions collected from reference books, we created 39 candidate situations that could elicit formulaic expressions. Third, the 39 scenarios were used to create a Chinese Discourse Completion Task (DCT) for Chinese native speakers (NSs). The DCT was piloted with 38 Chinese NSs in China (24 females and 14 males including three undergraduate students, 15 graduate students, and 20 professionals) to see if the situations could indeed elicit intended formulaic expressions. For each DCT item, the NSs read a situational scenario and wrote down what they would say in that situation. They also indicated whether or not the situation would occur regularly in their everyday life based on their own experience. Below is a sample item:

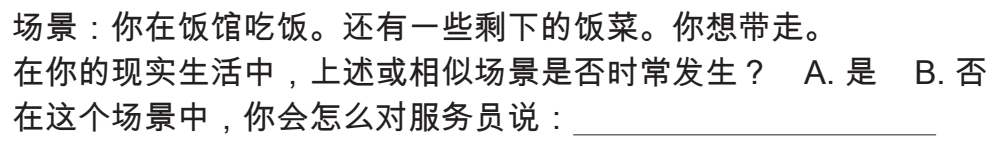

5 According to the Foreign Service Institute, 2,200 class hours are needed for native English speakers to reach Level 3 (General Professional Proficiency) on the Interagency Language Roundtable Scale. Based on this estimate, participants in this study fell below the advanced-level proficiency in Chinese.

6 The representative books that we consulted were: Chen, Z., and Y. Tian. 2006. Experiencing Chinese: Studying in China. Beijing: Higer Education Press. Yue, J., Y. Lu, X. Zhu, and P. Chu. 2009. Experiencing Chinese: Living in China. Beijing: Higher Education Press. Zhang, R. 2006. Experiencing Chinese: Travelling in China. Beijing: Higher Education Press. 
Scenario: You are having dinner in a restaurant. You would like to take the leftovers with you.

Does this situation happen regularly in your life? A. YES B. NO

What would you say to the waiter/waitress in this situation?

The NS data were analyzed to select target formulae-use situations. The situations that were judged as occurring regularly (i.e., choosing the YES option) by $50 \%$ of the NSs were retained. In addition, following Bardovi-Harlig (2009a), situations that generated single expressions that were used by at least $50 \%$ of the NSs were retained. After these screening processes, 24 scenarios (out of 39) were selected. Appendix 1 displays the 24 situations, along with the target formulae (see data analysis section for explanation), the percentage of the Chinese NSs who judged the situation as occurring regularly (context judgment), and the percentage of the Chinese NSs who produced the target formulae. For example, in Situation \#4 (Ordering in a restaurant), 37 out of 38 NSs (97.37\%) judged this situation as occurring frequently. In addition, 28 of out of 38 NSs (73.68\%) produced the target formulae, $\{$ 来/要\} \{个/份\}鱼香肉丝, $\{$ lái/yào\} \{gè/fèn\} yú xiāng ròu sī. $\{$ Order/need $\}+$ measure word + Yu xiang rou si (name of a Chinese dish).

\subsection{Data collection instruments}

Based on the results of the pilot study, a Computerized Oral Discourse Completion Task (CODCT) was developed by using the Revolution software program (Media Version) (2009). The task contained 24 target items, two practice items, and seven filler items. For each item, the participants first read and listened to a scenario description in English. Then, the scenario description disappeared. After a beep, the participants responded orally in Chinese with what they would say in that situation. Their oral responses were recorded in computers. See below for a sample CODCT item:

Item 3: In a market, you want to buy a T-shirt but you think it's a bit expensive. You want the vendor to lower the price. What would you say to the vendor?

The CODCT situations were presented in English to ensure the learners' understanding of the situations and also to prevent them from using the words appearing in scenario descriptions in their responses. While English descriptions might have induced transfer of L1 norms, the participants were explicitly instructed that all scenarios took place in China and involved interaction with a native speaker of Chinese. The participants were also told that when they felt it 
was most appropriate to opt out, they should say "say nothing," and when they did not know what to say in that situation, they should say "I don't know what to say."

We acknowledge weaknesses of the DCT instrument. While the DCT format was necessary to collect a large amount of data at once, it has been criticized because it lacks authenticity and participants have more time to plan their responses than in face-to-face interaction. Furthermore, although we were aware of the differences between oral and written data (Félix-Brasdefer 2010), we collected oral data in order to capture characteristics of natural spoken language (Yuan 2001).

In addition to the CODCT, the Formulae Contact Questionnaire (FCQ) was used to document the perceived amount of contact the participants had with target formulae-use situations. The FCQ contained short descriptions of the 24 target scenarios and asked the participants to write down, based on their semester-long study abroad experiences, how many times they thought they had encountered each situation. ${ }^{7}$ See sample items below:

How many times did you. ...

1. Withdraw money at a bank times

2. Bargain when shopping times

\subsection{Procedures}

The CODCT was administered twice to the participants, at the beginning and end of the semester, to see whether or not they improved in formulae production during study abroad ${ }^{8}$. The participants also completed the FCQ immediately after the posttest. Each participant received $\$ 7$ upon completing the posttest.

\subsection{Data analysis}

This study asked two questions: (1) whether or not L2 Chinese learners gained in formulaic competence during study abroad; and (2) whether or not there was any

7 One reviewer suggested using five-point scales as an alternative method to investigate frequency of encountering the target formulae-use situations. This suggestion should be considered in future research.

8 The study abroad program lasted for 14 weeks. The participants had final exams in Week 11 and travelled around China afterwards. Hence, we administered the post-CODCT at the end of Week 10. 
relationship between the perceived frequency of encounter of target formulae-use situations and gain in the ability to produce formulae. In this study, the learners' formulaic competence was analyzed based on three measures: (1) appropriateness rating of formulaic expressions, (2) frequency of production of target formulae, and (3) fluency in production of formulae.

For appropriateness rating, the second author and another Chinese NS with a background in applied linguistics rated each utterance on a four-point scale ranging from zero (i.e., impossible to evaluate) to three (i.e., almost target-like). The rubric focused on both form and meaning of learners' speech. Three points were assigned to an utterance that conformed to the raters' intuition of target-like expression. For instance, in Situation \#3 (Bargain), three points were given to the utterance 便宜点吧 (Pián yi diăn ba, “A little cheaper.”), as it was the target formulae in this situation.

Two points were given to an utterance when the form was slightly different from the target expression in that it contained minor grammatical and lexical errors and/or a few extra linguistic elements, but these errors did not obscure the meaning of the utterance. For example, for the same Bargain situation, the utterance 你可以便宜吗? (Nǐ kě yǐ pián yi ma? “Could you make it a little cheaper?”) received two points, since it contained unnecessary elements, that is, the subject 你 (Nǐ, you) and the modal verb 可以 (kě yǐ, could).

One point was given if the utterance was obviously non-native-like due to a non-typical way of saying (including code-switching) and/or serious grammatical and lexical errors that obscured the intended meaning. For example, the utterance 我要不太贵 (Wǒ yào bù tài guì, “I want it to be not too expensive.”) was judged as ungrammatical, non-typical way of responding to the Bargain situation. Hence, this utterance received one point.

Finally, a score of zero was given if a student opted out, or if the utterance did not make sense at all. For example, in Situation \#14 (Credit Card) in which the speaker wanted to know if he/she could use a credit card, the utterance 我可以用 钱吗? (Wǒ kě yǐ yòng qián ma? Can I use money?) received zero because this utterance was obviously misleading. All disfluency features (e.g., repetitions, pauses, false starts) were not considered in the evaluation.

The rating process went through several phases. Two judges first discussed the scoring rubrics with a few samples. Then, they independently rated 10 utterances selected randomly for each scenario. The ratings were compared, and all discrepancies were resolved. The two judges then independently rated the remaining utterances. The inter-rater reliability was high, $r=.93$. Discrepancies in rating (i.e., two points or more) were discussed and a consensus was reached.

In addition to the appropriateness rating, we examined fluency of formulae production. Fluency was measured as planning times, namely amount of time 
taken for production (see Taguchi 2007, for the description). Planning time was measured between the moment when the aural description of situation ended and the moment when the participants started speaking.

Finally, we analyzed the frequency of target formulaic expressions. The target formulae were identified in native speakers' data (collected through the DCT mentioned above) based on five criteria. First, a formula needed to be a multiword sequence. Second, an utterance was considered as a formulaic expression if it was uttered with continuous intonation and without internal pausing. For instance, when Chinese native speakers say 随便看看 (suí biàn kàn kan, “randomly looking”) to decline the help from a shop assistant, they do not pause between 随 便(suí biàn, “randomly”) and 看看 (kàn kan, “looking”). Third, an utterance was considered as a formulaic expression if it included fixed syntactic strings (e.g., 能 + verb, néng + verb, “Can” + verb), collocations (e.g., 刷(信用)卡, shuā (xìn yòng) kă, “swipe (credit) card”), and lexical phrases (不好意思, bù hăo yì si, “sorry”). Fourth, an utterance was considered as a formulaic expression if it contained interchangeable components that serve similar functions. For instance, in Situation \#6 (Try on a hat), although 试试 (shì shi), 试一试 (shì yi shì), and 试一 下儿 (shì yī xiàr) represented three different morphological structures, they all meant "have a try" with a softened tone, and thus they were considered as formulae. Finally, an utterance was considered as a formulaic expression if it was tied to a specific situation. For example 打包 (dǎ bāo, “wrap up”) typically occurs in restaurants when a customer wants to ask a waiter/waitress to help wrap up leftovers. ${ }^{9}$ See Appendix 1 for the list of target formulaic expressions found in the NS data.

After determining the target formulae based on the above criteria, the learners' expressions were compared with the target expressions, and frequency of the exact target expressions was counted. For instance, in the utterance 取300 人民币 (qǔ 300 rén mín bì, withdraw 300 RMB), the underlined part was the same as the target expression 取300 (qǔ 300, withdraw 300). Hence, it was included in the count. However, the utterance 要300块 (yào 300 kuài, want 300 kuai $^{10}$ ) did not contain the target expression. Hence, it was excluded from the count. Two

9 We did not find any formulae that met the criterion of "syntactic irregularity". Communitywide use of the selected formulae was self-evident, since the native speaker participants reflected variations in gender, age, and profession. Whether the formulae were stored as holistic units in native speakers' mind would require a separate psycholinguistic study, which was not the purpose of this paper. For complementary means for identifying Chinese situation-bound utterances, see Zhou (2012).

10 "Kuai" is a unit of Chinese currency. 
Chinese native speakers independently coded $20 \%$ of randomly selected utterances, yielding the agreement ratio of $99.03 \%$.

\section{Results}

\subsection{Quantitative analysis}

The first research question asked whether or not L2 learners of Chinese gained in producing formulae in a target-like manner during study abroad. Table 1 presents the means and standard deviations of appropriateness ratings, planning times, and the frequency of target formulae production at pre- and posttest. The $t$-test results revealed that the learners made significant gains in appropriateness ratings over time, $t(30)=-8.54, p<.01, \mathrm{n}^{2}=0.71$. A post hoc analysis was conducted to compare the pre- and posttest ratings for each formulae-use situation. Nine out of 24 situations showed significant improvement. In addition, the learners' planning time was significantly shorter at posttest than at pretest, $t(30)=2.093$, $p=0.045, \mathrm{n}^{2}=0.13$. Finally, the Wilcoxon test results revealed that the learners produced the target formulae significantly more frequently at posttest than at pretest, $\mathrm{Z}=-3.50, p<.01, \mathrm{n}^{2}=0.41$.

The second research question addressed the relationship between the perceived frequency of encountering target formulae-use situations and gains in formulae production. There was no significant relationship between the reported frequency of encounter and gains in appropriateness rating $(r=-0.161, p=0.452)$, or planning time $(r=-0.088, p=0.683)$, or frequency of target formulae production $(r=0.201, p=0.347)$.

A post hoc regression analysis was used to test the interaction effect between the reported frequency of encounter of formulae-use situations and the partici-

Table 1: Descriptive Statistics of Rating, Planning Times, and Frequency of Target Formulae

\begin{tabular}{lllll}
\hline & Appropriateness & Planning time & $\begin{array}{l}\text { Frequency of target } \\
\text { formulae }\end{array}$ \\
\hline Pretest $(N=31)$ & Mean & $1.10^{\star}$ & 1.62 & $2.90^{\star \star}$ \\
& $S D$ & 0.37 & 0.77 & 1.92 \\
Posttest $(N=31)$ & Mean & 1.43 & 1.39 & 4.48 \\
& $S D$ & 0.31 & 0.63 & 2.20 \\
\hline
\end{tabular}

Note. ${ }^{*}$ The score range is $0-3 ;{ }^{* *}$ the score range is $0-24$. 
Table 2: Effect of Frequency Encounter and Pre-test Score on Appropriateness Gain

\begin{tabular}{lcc}
\hline & Standardized coefficients (Beta) & \multicolumn{1}{c}{$\boldsymbol{t}$} \\
\hline Frequency of encounter & .0095 & $5.099^{\star}$ \\
Frequency of encounter and pre-test score & -.0079 & $-8.17^{\star}$ \\
R-squared & .18 & \\
\hline${ }^{*} p<.001$ & & \\
\hline
\end{tabular}

pants' pretest appropriateness scores on gains (pre-post score difference). This interaction effect was checked because participants with a high pretest score obviously had less room to grow. In addition, because the frequency of encounter and the pretest score were found to be correlated, the analysis of the interaction effect of these two variables was considered to provide a more precise picture of the effect of learning context on formulae acquisition.

In the regression, the independent variable was the frequency of encounter of the formulae-use situations, and the product (or interaction) of frequency and pretest appropriateness scores. The dependent variable was gain in the appropriateness scores. Frequency of encounter had a significant effect on gain, Beta $=.0095(p<.001)$ (Table 2). There was a significant negative interaction between the product of frequency and pre-test score, and gain, Beta $=-.0079$ $(p<.001)$. Hence, frequency of encounter was found to have a small but significant effect for the learners who had low pretest scores. In other words, the learners who started out with low appropriateness scores benefited more from (perceived) frequency of encounter during study abroad. The frequency and the product of frequency and pretest score jointly explained $18 \%(r$-squared $=.18)$ of the dependent variable (i.e., gain).

\subsection{Qualitative analysis}

Qualitative analysis on the learners' production data was conducted to explore patterns of formulae development during study abroad. We searched in pre- and posttest data sets for dominant expressions, defined as those produced by at least $20 \%$ of the learners for any given situation. We decided to use the $20 \%$ cutoff point after a thorough examination of the entire data set. Given the fact that the learners' responses to the formulae-use situations were mostly idiosyncratic, this cut-off point was determined as appropriate for capturing the maximum level of variation in learners' production while ensuring representativeness of the expressions included for analysis. 
Appendix 2 displays the learners' dominant expressions, as well as the target formulae produced by NSs. Analysis revealed four general patterns of change: Category I, change toward target formulae; Category II, change toward target-like slot-and-frame patterns; Category III; change toward non-target formulae; and Category IV, fossilized non-target formulae. These categories appear in Appendix 2. The following sections provide a more detailed analysis for each category. In learners' expressions, alternations of formulae were shown in curly brackets \{\} divided by slashes. Optional elements were shown in parentheses. The target formulae were highlighted in italics with bold font. Each Chinese expression was followed by its Pinyin version (a Chinese transliteration system) and by English translation.

Category I: Change toward target formulae. This category was characterized with increased use of target formulae from pre- to posttest. For example, in situation \#12 (Wrong phone call), the learners' production of the target formulae 打错 了 (dǎ cuò le, "made wrong phone call”) increased from 6.45\% to 22.58\% over time. Meanwhile, their use of the non-target expression 对不起 (duì bu qǐ, sorry) dropped from $51.61 \%$ to $38.71 \%$. Noticeably, the pace of development toward the target formulae varied within this category. This might be explained by the learners' prior formulaic knowledge (reflected in their performance at pretest). For instance, in Situation \#10 (Washroom), the expression $\{$ 卫生间/洗手间/则所 $\}$ 在哪儿?(\{wèi shēng jiān/xǐshǒu jiān/cè suǒ \} zài nǎr? "Where is the washroom?”) showed the least development over time. This was probably due to a ceiling effect because $80.65 \%$ of the learners were able to produce the target form at pretest. On the other hand, the expression \{来/要\} \{个/份 $\}$ 鱼香肉丝 (\{lái/yào\} \{gè/fèn\} yú xiāng ròu sī, \{Order/want\} MW yu xiang rou si ${ }^{11}$ ) showed the largest gain. Interestingly, while only three learners produced this exact expression at pretest, eight produced a similar yet simplified expression \{来/要\}鱼香肉丝 (\{lái/yào\} yú xiāng ròu sī, \{Order/want\} Yu xiang rou si). The difference between these two expressions was use of the measure word (e.g., 个/份, gè/fèn). Hence, the relatively fast pace of development observed for the expression $\{$ 来/要 $\}\{$ 个/份 $\}$ 鱼香肉丝 (\{lái/ yào\} \{gè/fèn\} yú xiāng ròu sī, \{Order/want\} a yu xiang rou si) was probably because the learners already had a simpler version of this expression in their repertoire. During study abroad, learners probably learned to add appropriate measure words to this simpler version. This interpretation was supported by the fact that four of the eight learners who used the simplified expression at pretest produced more elaborated target expressions at posttest.

11 MW stands for Measure Word; yú xiāng ròu sī is the name of a Chinese dish. 
In addition, development was found on formulaic expressions that contained a few unnecessary elements added to the target formulae. For instance, in Situation \#16 (Ask for price), while the learners' gain in the use of the exact target expression 苹果多少钱? (píng guǒ duō shăo qián? “How much is the apple?”) was only modest, they made considerable gains in producing another expression: $\{$ 一个/这个\}苹果多少钱? (\{yī gè/zhè gè \} píng guǒ duō shǎo qián? “How much is \{one MW/this MW\} apple?"), an expression that contained the redundant pronoun + measure word structure (i.e., 这个, zhè gè, this + MW) or quantification structure (i.e., 一个, yī gè, one + MW). In contrast to the elaboration mentioned earlier, in order to progress toward the target expressions, the learners' task here was to drop the redundant components from their interlanguage formulae, a process that could be termed "simplification." In fact, there was one learner who produced the interlanguage form at pretest but produced the target expression at posttest.

In summary, Category I represented a pattern of development toward the target formulae. The learners might achieve this goal through elaboration and/or simplification processes.

Category II: Change toward target-like slot-and-frame patterns. The defining feature of this category was the increased production of the slot-and-frame patterns shared by the target formulae. In other words, although the learners fell short of producing the exact form of target formulae, they approximated the targets by producing target-like patterns with open slots. Typically, these open slots were for precise, native-like lexical items. The learners in this study, with somewhat impoverished L2 vocabulary knowledge, adopted various paraphrasing strategies, which led to various idiosyncratic expressions. A revealing example came from Situation \#17 (Cashier), in which the learners increased their production of the pattern verb phrase + 在哪儿 (verb phrase + zài năr, verb phrase + "in where") over time. Note that the pattern was the same as the target expression, \{收银台/款台\}在 $\{$ 哪/哪里/哪边\}? (\{shōu yín tái/kuăn tái\} zài \{nǎ/nǎ lǐ/nǎ biān\}? "Where is the cashier?”) . The difference was that the Chinese noun for cashier was replaced by different verb phrases that conveyed the meaning of "purchasing" or "purchasing things". This resulted in the following nontarget-like utterances ${ }^{12}$ : 付钱在哪儿? (fù qián zài nǎr? “spend money in where?”); 付在哪儿? (fù zài nǎr? “spend in where?”); 可以买这个东西在哪儿? (kě yǐ mǎi zhè ge dōng xi zài năr? “Could buy this thing in where?”); 可以买这个在哪儿?

12 These expressions were ungrammatical in Chinese because a verb phrase cannot be placed before the preposition phrase 在哪儿 (zài năr, in where). 
(kě yǐ mǎi zhè ge zài năr? “Could buy this in where?”). These expressions, though idiosyncratic, demonstrated the learners' awareness of target formulae structures.

In other cases, the learners seemed lacking lexical and syntactic knowledge to refine their target-like slot-and-frame patterns. For example, in Situation \#6 (Try on a hat), learners made large improvement in using the interrogative structure with the modal verb 可以 (kě yǐ, “could”) and their own choice of verbs. Here, two major factors constrained their ability to produce the exact target expression: (1) use of learner-specific verbs (e.g., 戴, dài, “to put on”; 穿, chuān, “to wear”), which was different from native-like verbs (i.e., 试 shì, "to try”), and (2) the lack of the sentence final question word 吗 (ma) (as a result the entire expression became ungrammatical).

In summary, Category II revealed another pathway toward native-like formulaic competence, i.e., through the development of target-like slot-and-frame patterns. Our analyses showed that appropriate grammatical (i.e., lexical and syntactic) knowledge is necessary before the learners become able to produce the exact target formulae.

Category III: Change toward non-target formulae. A distinct feature of this category was the increased use of non-target formulae over time. However, interestingly, in parallel with this divergent developmental pattern at the surface level, the learners also increased their production of correct constituent elements (typically core lexical elements) of the target formulae. An example comes from Situation \#18 (Ask for direction). In this situation, the most noticeable change was the learners' increased production of 怎么\{去/到 $\}$ 北京大学? (Zěnme \{qù/dào\} Běijīng Dàxué? How to get to Peking University?) from $6.45 \%$ to $22.58 \%$. Although this expression was different from the target expression, it shared the question word 怎么 (zěnme, how). This question word is the critical lexical element that allows the speaker to produce a question asking about the means of doing something. When this question word is followed by verbs meaning "to go" and/or "to arrive", it enables the speaker to ask for direction. This is what the learners became able to do over time. The increased use of the non-target formula thus might represent a process in which the learners strengthened the use of a lexical core for the target expression. The developmental mechanism emerging from this category, then, can be described as building up a lexical core.

The only exception in this category comes from Situation \#13 (Empty seat). Here, the learners increased their production of the non-target pattern 我可以/可 以不可以\}坐 + noun phrase (Wǒ \{kěyǐ/kěyǐ bù kěyǐ zuò + noun phrase? I \{may/ may or may not\} sit + noun phrase). Unlike other cases in this category, this interlanguage pattern did not contain any element of the target expression $\{$ 这儿/这 里/这/这个位置\}有人吗? (\{zhèr/zhèli/zhè/zhège wèizhi\} yǒu rén ma? \{here/here/ 
this/this seat has person $\mathrm{QW}$ ? $^{13}$ ). The learners used a different form to realize the function of checking the availability of the seat. While this example points to the learners' lack of appropriate pragmalinguistic knowledge, ${ }^{14}$ the increased use of this interlanguage pattern also suggests that the learners were making an effort to master this native-like linguistic form to convey their communicative intention.

Category IV: Stabilized non-target formulae use. This category was characterized with the consistently high percentage of non-target expressions over time. In this category, the learners were able to convey communicative intention despite their use of non-target-like forms. There was a tendency for the learners to stick to the same form to realize a particular communicative function whereas the NSs' selections of forms varied according to situations. For example, in the three leavetaking situations (\#5, \#15, \#19), the learners consistently used the generic farewell expression 再见 (zài jiàn, again see, functionally as "goodbye”). However, the NSs' choices of farewell expressions varied to reflect the nuances of different leave-taking situations. In Situations \#5 (Leave friend's home) and \#19 (Leave a party early) that represented physical leave-taking, the formulae preferred by the NSs shared the core element 走了 (zǒu le, “leaving”). However, the NSs used intensifiers (i.e., the modal verb 得, děi, “have to”, or the adverb 先, xiān, “first”) for Situation \#19 to acknowledge an abrupt leave-taking in the middle of a party. The use of these intensifiers was optional for Situation \#5, since this was a natural (not abrupt) leave-taking situation - the guest was expected to leave in late evening. Different from these two situations, Situation \#15 (End a phone call) represented a context of non-physical leave-taking, and the NSs used \{ 就/先\}这样 (\{jiù) xiān\} zhè yàng, "that is it"). These examples showed that NSs adjusted their formulaic expressions according to different leave-taking situations. The learners, however, seemed to lack this pragmalinguistic knowledge, which prevented them from appreciating the subtleties of different farewell situations through their expressions.

Another factor that led to the stabilized use of non-target expressions was learners' lack of sociopragmatic knowledge. For instance, in Situation \#22 (Pass a crowd), the majority of the NSs $(60.53 \%)$ favored a direct request $\{$ 麻烦/请 $\}$ \{让一 下/让一让/过一下\} (\{máfan/qǐng\} \{ràng yi xià/ràng yi ràng/guò yi xià\}, "Please move a bit”). In contrast, 17 learners (54.84\%) preferred 对不起 (duì bu qǐ, “sorry"), a term for expressing apology in Chinese. Another example comes from

13 QW stands for Question Word.

14 According to Leech (1983), pragmalinguistic knowledge refers the mappings between linguistic forms and the illocutionary forces that these forms convey. Sociopragmatic knowledge, on the other hand, refers to the mappings between contextual factors (e.g., power, social distance, degree of imposition) and communicative actions. 
Situation \#21 (Call Professor Wang). Here, the majority of the NSs chose to confirm that the interlocutor was the person they were looking for by saying 请问是 王老师吗? (qǐng wèn shì Wáng lăo shī ma? “May I ask if it is Professor Wang?”)15. In contrast, the learners predominantly (54.84\% in both pre- and posttest) used the greeting expression 你好 (nǐ hăo, “you good”, functionally equivalent to "Hello"). A closer examination of the learner data further revealed that the learners' use of 你好 (nǐ hăo, "Hello") was typically combined with self-introduction (e.g., 这是罗兰, zhè shì Luó Lán, “This is Lauren”) and/or checking the availability of the person whom they were looking for (e.g., 王老师在吗? Wáng lǎo shī zài ma? "Is Professor Wang in there?," which is functionally equivalent to "May I speak to Professor Wang”?). These examples show that the learners had a different set of context-action mappings compared with the NSs, leading to their stabilized use of non-target formulae.

\section{Discussion}

The first research question asked whether or not L2 learners of Chinese gained in their ability to produce formulaic expressions during study abroad. Results showed that, over a 10 -week study abroad, the learners demonstrated significant gains in appropriateness scores and frequency of target formulae. They also increased the planning speed, indicating that they became more efficient in retrieving lexico-syntactic knowledge necessary for target formulaic expressions. These results were in line with previous findings focusing on the role of study abroad context in promoting L2 formulaic competence (e.g., Roever 2005, Taguchi 2011).

The second research question asked whether there was any relationship between the perceived frequency of encounter of target formulae-use situations and gains in production. Pearson correlation analysis did not show significant correlations. However, the post hoc regression analysis showed that the learners' initial scores and perceived frequency of encounter together explained the gains. Hence, it seems that the gains in formulae production were likely to be influenced by learners' initial level of formulaic competence in relation to the frequency of encounter of target formulae-use situations. Qualitative analyses (see 4.2) revealed additional sources of influence, including lexical and syntactic knowledge, as well as knowledge of form-context mappings. Below we will discuss these findings in more detail.

15 Some NSs also incorporated greeting expressions with the respectful personal pronoun 您 (nín, you) as in 您好 (nín hăo, hello). However, the use of 您好 did not reach the 50\% cut-off line. 


\subsection{Appropriateness rating of formulae production}

Despite the overall significant gains found in this measure, the mean ratings for the learners' performance in 21 out of the 24 formulae-use situations still fell below Band 2 at posttest, and the mean rating was 1.43 for the 24 situations combined. According to the scoring rubric, this meant that the learners were able to convey their communicative intention but fell short of native-like use of form. Meanwhile, we also found that the nine formulae-use situations that showed significant gains over time all received below group average at pretest (i.e. 1.10). These results suggest that the learners in this study probably focused more on meaning than on form during study abroad. This interpretation received support from the results of the post hoc regression analysis. Perceived frequency of encounter was found to have a larger impact on the gain for learners with lower pretest ratings than for learners with higher pretest ratings. In other words, the effects of frequency of encounter on the gain in ratings were mediated by the learners' level of formulaic competence at the beginning of their study abroad. When presented with numerous pressing needs of "getting the message across" in the study abroad context, the learners with relatively limited formal Chinese study (on average 3.4 semesters of Chinese instruction) seemed to be less invested on improving their linguistic forms as long as their interlanguage forms were sufficient to get by.

These findings provide additional insights into our understanding of the role of study abroad on L2 formulaic development. It has been acknowledged that a study abroad context can provide ample opportunities for encountering target formulaic expressions (e.g., Dornyei et al. 2004). Our findings further suggest that the advantage of studying abroad (i.e., frequent encounter of target formulae-use situations) is not unqualified. Rather, the effect of study abroad context on formulaic competence could be understood when other factors (e.g., the initial level of formulaic competence) are considered.

\subsection{Frequency of production of the target formulae}

In addition to appropriateness ratings, learners also made significant gains over time in the production rate of the target formulaic expressions. However, close analysis of individual formulae revealed a complex picture. Qualitative analysis identified four patterns of change: Category I, change toward target formulae, Category II, change toward target-like slot-and-frame patterns, Category III, change toward non-target formulae, and Category IV, stabilized non-target formulae use. The coexistence of these categories suggests that the development of 
formulae production is not a homogeneous process; it is characterized with parallel processes of convergence (Category I, II), divergence (Category III), and stabilization (Category IV).

The production of exact target formulae remained fairly limited even toward the end of the sojourn. While the correlation analysis showed no relationship between perceived frequency of encounter of target formulae situations and gains in frequency of native-like production, qualitative analysis identified several possible factors that prevented the learners from producing the exact target formulae: lack of lexico-syntactic knowledge, and lack of pragmalinguistic and/or sociopragmatic knowledge. These results complemented previous cross-sectional studies on the development of L2 formulaic competence, adding to the generalizability of the findings (e.g., Bardovi-Harlig 2009a, Bardovi-Harlig et al. 2010).

From an acquisitional perspective, it is important to discuss the mechanisms underlying the development of formulaic competence (i.e., patterns that learners exhibit when progressing toward native-like formulaic competence). Our participants demonstrated a trend of elaboration and simplification toward the target formulae (Category I). They also gradually developed the slot-and-frame patterns that constituted the core structure of the target formulae (Category II). Furthermore, the learners were found to increase the use of core lexical items that were part of the target formulae (Category III). Interestingly, what lies in the core of these developmental mechanisms seems to be broadly defined grammatical knowledge (i.e., lexical and syntactic knowledge). This observation was in line with previous cross-sectional studies that concluded that L2 formulae use was partially dependent on grammar (e.g., Bardovi-Harlig 2009a, Bardovi-Harlig et al. 2010). Different from previous studies which generally revealed development toward the target-like formulae use, the mechanisms discussed here revealed both convergent and divergent patterns of development. It seems that interlanguage grammar system serves as a driving force for changing L2 formulaic competence.

In contrast, stabilization due to inadequate pragmalinguistic and/or sociopragmatic knowledge (Category IV) seemed to be highly resistant to change over time. As shown in the case of the three leave-taking situations, the learners tended to over-generalize one expression to different situations that required the use of different formulae. This overgeneralization was likely due to the learners' limited pragmalinguistic repertoire in leave-taking. In addition, the three formulae that accounted for much of the L2 data in this category, i.e., 你好 (nǐ hăo, “hello”, literally means “you good”), 对不起 (duì bu qǐ, “sorry”), and 再见 (zài jiàn, "Goodbye”, literally means "again see”) are typically introduced at the beginning phase of Elementary Chinese courses as expressions with generic communicative functions (i.e., greeting, apology, and leaving taking). Hence, it is 
likely that these form-function associations were so deeply entrenched in the learners' interlanguage system that they stopped incorporating alternative forms for conveying similar functions as long as they were able to get their meaning across with these generic-function formulae. This probably resulted in the learners' stabilized use of these formulae regardless of different communicative situations. While this study revealed stabilization of learner-specific expressions over time, which was not discussed in previous studies, it should be kept in mind that the study period was relatively short (i.e., one semester). Hence, whether the stabilization found in this study is a temporal or permanent phenomenon remains to be seen.

Although formulaic expressions are conventionalized linguistic forms tied to specific communicative functions and situations, L2 learners seem to prioritize conveying meaning over using target-like linguistic forms. This is most clearly illustrated by Category III, in which the learners shifted to using non-target linguistic patterns to get their meaning across, and by Category IV, in which the learners over-generalized the formulae they knew (Category IV) (e.g., the use of 再见, zài jiàn, “goodbye”, in the three leave-taking situations). Hence, the learners in this study seemed to be at what Kasper and Rose (2002) illustrated as early phrases of development, in which learners "build on their available pragmatic knowledge, making do with whatever L2 grammar they have and at the same time acquiring the grammar needed to accomplish actions in L2" (p. 187). It may be worth exploring whether and how the learners would eventually achieve "nativelike selection" (Pawlye and Syder 1983) of conventionalized linguistic forms in context.

\section{Limitations, future directions, and implications for teaching}

This study revealed gains in formulae production in L2 Chinese during study abroad. We found multiple factors affecting the change, including frequency of encounters of target formulae-use situations, initial level of formulaic competence, lexico-syntactic knowledge, and availability and/or lack of pragmalinguistic and sociopragmatic knowledge. This study suggests that the widely claimed advantage of study abroad for L2 development needs to be investigated in relation to multiple intervening factors, at least in future studies on the development of formulaic competence. The study also revealed four general patterns of change in L2 formulae production. These patterns illustrate the complexity involved in the development and call for more fine-grained investigations into L2 formulae competence. 
Future research with a longer study period is necessary in order to confirm the generalizability of the present findings. For instance, as found in this study, a potential contributing factor to formulaic competence is the use of core lexical items in the target formulae. The study also found that the learners increased the use of core lexis but the remaining elements in their expressions did not approximate target-like forms. Hence, it is important to investigate whether or not the learners continue working on the lexical core while moving toward the direction toward target formulae. Similarly, because the learners in this study overgeneralized specific formulaic expressions, future research should examine at which point learners stop over-generalizing and start incorporating alternative, native-like formulae into their interlanguage systems.

Another limitation of this study relates to the survey used to measure the learners' contact with formulaic expressions. This study measured reported frequency of contact at the end of the study abroad period, but qualitative methods such as interviews and observations could reveal individual learners' experiences with formulaic expressions. In addition, the survey asked about the learners' direct contact with individual expressions and did not ask about their receptive experiences. In a study abroad context, learners produce formulaic expressions as much as they hear the expressions. Future research should adopt a more finetuned instrument that helps examine learners' experiences in production and comprehension of formulaic expressions.

In addition, future research should combine qualitative methods such as interviews or introspective verbal reports in order to gain insight on learners' understanding of formulaic expressions. It is possible that the learners knew the expressions but were not able to produce them, or they could produce them without explicit understanding. Qualitative data could reveal learners' awareness and understanding of formulaic expressions, which provides additional insight into their formulaic competence.

Finally, the present findings offer several implications for teaching. First, it is necessary to introduce formulaic expressions early on in a language curriculum. Unfortunately, in the current Chinese-as-a-foreign/second-language education, instructional focus has been placed on pronunciation, characters, and basic grammatical structures. This practice needs to be expanded in the future to include instruction on formulaic expressions (see Bardovi-Harlig and Vellenga 2012). Since learners' formulaic development was found to be closely related to their interlanguage grammar, classroom instructors can emphasize communicative functions of individual formulaic expressions. For example, teachers can make learners aware of the leave-taking function of some phrases such as 走了 (zǒu le, “leaving”) and \{就/先\}这样 (\{jiù/xiān\} zhè yàng, “that is it”). Once learners master several leave-taking forms, we could expose them to a range of farewell sce- 
narios that require the use of those forms. Teachers can ask them to compare contextual characteristics of different leave-taking scenarios and connect them to the target formulae. On the other hand, because learners sometimes misinterpret formulae-use situations and produce a non-native-like expression (as shown in Category IV), teachers can incorporate activities targeted at sociopragmatic knowledge. One such activity involves cross-linguistic comparison of formulae in situation. Teachers can ask learners to compare expressions between their native and target language contexts. We believe that formulaic competence in L2 Chinese can be promoted through these classroom activities, and future research is needed to explore the effective pedagogical means for achieving this goal.

\section{References}

Altenberg, Guilermo. 1998. On the phraseology of spoken English: The evidence of recurrent word-combinations. In Anthony Paul Cowie (ed.), Phraseology (pp. 101-122). Oxford: Claredon Press.

Bardovi-Harlig, Kathleen. 2007. Recognition and production of formulas in L2 pragmatics. In Understanding second language process (pp. 205-222). Clevedon, England: Multilingual Matters.

Bardovi-Harlig, Kathleen. 2009a. Conventional expressions as a pragmalinguistic resource: Recognition and production of conventional expressions in L2 pragmatics. Language Learning 59: 755-795.

Bardovi-Harlig, Kathleen. 2009b. Recognition of conventional expressions in L2 pragmatics. In Gabrielle Kasper, Dina Yoshimi, Hanh Thi Nguyen and Jim Yoshioka (eds.), Pragmatics and Language Learning (vol. 12), Honolulu, HI: Second Language Teaching and Curriculum Center, University of Hawaii.

Bardovi-Harlig, Kathleen. In press. Formulas, routines, and conventional expressions in pragmatics research. Annual Review of Applied Linguistics 25.

Bardovi-Harlig, Kathleen, Bastos Marua-Thereza, Beatrix Burghardt, Eric Chappetto, Nickels Edelmira and Rose Marda. 2010. The use of conventional expressions and utterance length in L2 pragmatics. In Gabrielle Kasper, Hanh Thi Nguyen, Diana Rudolph Yoshimi, and Jim. K. Yoshioka (Eds.). Pragmatics and Language Learning, Vol. 12 (pp. 163-186). Honolulu, National Foreign Language Resource Center.

Bardovi-Harlig, Kathleen, and Heidi Vellenga. 2012. The effect of instruction on conventional expressions in L2 pragmatics. System 40: 77-89.

Blum-Kulka, Shoshana and Elite Olshtain. 1986. Too many words: Length of utterance and pragmatic failure. Studies in Second Language Acquisition 8: 165-180.

Byram, Michael. 1997. Teaching and Assessing Intercultural Communicative Competence. United Kingdom: Multilingual Matters.

Chen, Zuohong, and Yan Tian. 2006. Experiencing Chinese: Studying in China. Beijing: Higher Education Press.

Conklin, Kathy and Nobert Schmitt. 2008. Formulaic sequences: Are they processed more quickly than nonformulaic language by native and nonnative speakers? Applied Linguistics 29: $72-89$. 
Coulmas, Florian. 1981. Conventional Routine: Exploration in Standarized Communication Situations and Prepatterned speech. The Hague: Mouton.

De Cock, Sylvie. 1998. A recurrent word combination approach to the study of formulae in the speech of native and non-native speakers of English. International Journal of Corpus Linguistics 3: 59-88.

Dewey, Dan. 2004. A comparison of reading development by learners of Japanese in intensive domestic immersion and study abroad contexts. Studies in Second Language Acquisition 26: 303-327.

Dornyei, Zoltan, Valerie Durow, and Khawla Zahran. 2004. Individual differences and their effects on formulaic sequence acquisition. In Nobert Schmitt (ed.), Formulaic Sequences (pp. 87-106). Amsterdam/Philadelphia: John Benjamins.

Ellis, Nick. 2003. Constructions, Chunking, and Connectionism: The emergence of second language structure. In Catherine Doughty and Mike Long (eds.), Handbook in SLA (pp. 63-103).

Ellis, Nick, Rita Simpson-Vlach and Carson Maynard. 2008. Formulaic language in native and second language speakers: Psycholinguistic, corpus linguistic, and TESOL. TESOL Quarterly 42: 375-396.

Félix-Brasdefer, César. 2010. Data collection methods in speech act performance: DCTs, role plays, and verbal reports. In Alicia Martínez-Flor and Esther Usó-Juan (eds.), Speech Act Performance: Theoretical, Empirical, and Methodological issues (pp. 41-56). Amsterdam: John Benjamins.

Freed, Barbara, Dan Dewey and Norman Segalowitz. 2004. The language contact profile. Studies in Second Language Acquisition 26: 349-356.

Hakuta, Kenji. 1974. Prefabricated patterns and the emergence of structure in second language acquisition. Language Learning 24: 287-298.

House, Julian. 1993. Toward a model for the analysis of inappropriate responses in native/ non-native interactions. In Gabrielle Kasper and Shohana Blum-Kulka (eds.), Interlanguage Pragmatics (pp. 161-183). New York: Oxford University Press.

House, Julian. 1996. Developing pragmatic fluency in English as a foreign language: Routines and metapragmatic awareness. Studies in Second Language Acquisition 18: 225-252.

Jiang, Nang and Nekrasova, Tanya. 2007. The processing of formulaic sequences by second language speakers. Modern Language Journal 91: 433-445.

Kasper, Gabrielle and Kenneth Rose. 2002. Pragmatic Development in a Second Language. Oxford, UK: Blackwell Publishing.

Kecskes, Istvan. 2000. Conceptual fluency and the use of situation-bound utterances. Links and Letters 7: 145-161.

Kecskes, Istvan. 2003. Situation-Bound Utterances in L1 and L2. Berlin: Mouton de Gruyter. Kinginger, Celeste. 2008. Language learning in study abroad: Case studies of Americans in France. Modern Language Journal, monograph.

Krashen, Stephen and Scarcella, Robin. 1978. On routines and patterns in language acquisition and performance. Language Learning 28: 283-300.

Lakoff, George and Mark Johnson. 1980. Metaphors We Live by. Chicago, IL: University of Chicago Press.

Leech, George. 1983. Principles of Pragmatics. London, UK: Longman.

Myles, Florence, Rosamond Mitchell and Janet Hooper. 1999. Interrogative chunks in French L2: A basis for creative construction? Studies in Second Language Acquisition 21: 49-80. 
Nattinger, James and DeCarrico, Janette. 1992. Lexical Phrases and Language Teaching. Oxford: Oxford University Press.

Pawley, Andrew and Frances Syder. 1983. Two puzzles for linguistic theory: Native-like selection and native-like fluency. In Jack Richards and Richard Schmidt (eds.), Language and Communication (pp. 191-226). London: Longman.

Pawley, Andrew and Frances Syder. 2000. The one-clause-at-a-time hypothesis. In Heidi Riggenbach (ed.), Perspectives on Fluency (pp. 163-199). Ann Arbor: University of Michigan Press.

Pérez-Vidal, Carmen and Maria Juan-Garau. 2009. The effect of study abroad (SA) on written performance. In Leah Roberts (ed.), EUROSLA Yearbook, Volume 9 (pp. 269-295). Amsterdam/Philadelphia: John Benjamins.

Riley, Philip. 1989. Well, don't blame me! On the interpretation of pragmatic errors. In Wieslaw Olesky (ed.), Contrastive Pragmatics. Amsterdam: John Benjamins.

Revolution (Media Version). 2009. Revolution [Computer software]. Edinburgh, UK: Runtime Revolution Ltd.

Segalowitz, Norman, and Barbara Freed. 2004. Context, contact, and cognition in oral fluency acquisition. Studies in Second Language Acquisition 26: 175-201.

Roever, Carsten. 2005. Testing EFL Pragmatics. Frankfurt: Gunter Narr.

Schmidt, Richard. 1983. Interaction, acculturation, and the acquisition of communicative competence. In Netta Wolfson and Elliot Judd (eds.), Sociolinguistics and Language Acquisition (pp. 137-174). Rowley, MA: Newbury House.

Schmitt, Nobert. 2004. Formulaic Sequences. Amsterdam: Benjamins.

Schmitt, Nobert, Zoltan Dornyei, Svenja Adolphs and Valerie Durow. 2004. Knowledge and acquisition of formulaic sequences: A longitudinal study. In Nobert Schmitt (ed.), Formulaic Sequences (pp. 55-86). Amsterdam: John Benjamins.

Schmitt, Nobert and Ronald Carter. 2004. Formulaic sequences in action. In Nobert Schmitt (ed.), Formulaic Sequences (pp. 1-22). Amsterdam: John Benjamins.

Schmidt, Richard and Frota, S. 1986. "Developing basic conversational ability in a second language: A case study of an adult learner of Portuguese." In Richard Day (ed.), Talking to Learn: Conversation in Second Language Acquisition (pp. 237-326). Rowley, MA: Newbury House.

Taguchi, Naoko. 2007. Task difficulty in oral speech act production. Applied Linguistics 28: 113-135.

Taguchi, Naoko. 2008. Cognition, language contact, and the development of pragmatic comprehension in English as a second language. Language Learning 58: 33-71.

Taguchi, Naoko. 2009. Corpus-informed assessment of L2 comprehension of conversational implicatures. TESOL Quarterly 43: 738-749.

Taguchi, Naoko. 2011. The effect of $L 2$ proficiency and study abroad experience in pragmatic comprehension. Language Learning 61: 904-939.

Thomas, Jenny. 1983. Cross-cultural pragmatic failure. Applied Linguistics 4: 91-112.

Warga, Muriel. 2005. "Je serais tres merciable": Formulaic vs. creatively produced speech learners' request-closings. Canadian Journal of Applied Linguistics 8: 67-93.

Wood, David. 2006. Uses and functions of formulaic sequences in second language speech: An exploration of the foundations of fluency. Canadian Modern Language Journal 63: 13-33.

Wildner-Bassett, Mary. 1984. Improving Pragmatic Aspects of Learners' Interlanguage. Tübingen: Gunter Narr. 
Wray, Alison. 2000. Formulaic sequences in second language teaching: Principle and practice.

Applied Linguistics 21: 463-489.

Wray, Alison. 2002. Formulaic Language and the Lexicon. Cambridge: Cambridge University Press.

Yuan, Yi. 2001. An inquiry into empirical pragmatics data-gathering methods: Written DCTs, oral DCTs, field notes, and natural conversations. Journal of Pragmatics 33: 271-292.

Zhang, Rumei and Ai Xin. 2006. Experiencing Chinese: Travelling in China. Beijing: Higher Education Press.

Zhou, Honghui. 2012. A study of situation-bound utterances in modern Chinese. Chinese as a Second Language Research 1: 55-86.

Zhu Xiaoxing, Jianling Yue, Yuhong Lu, Peiru Chu, and Qunshen Xu. (2006). Experiencing

Chinese: Living in China. Beijing: Higher Education Press.

\section{Appendix 1: Target situations, target formulaic expressions and frequency of use}

\begin{tabular}{|c|c|c|c|c|}
\hline Item & Scenario description & $\begin{array}{l}\text { Context } \\
\text { judgment } \\
(\mathrm{N}=38)\end{array}$ & Target formulaic expressions* & $\begin{array}{l}\text { Freq. of } \\
\text { use }(\mathrm{N}= \\
38)^{\star \star}\end{array}$ \\
\hline 1 & $\begin{array}{l}\text { Money withdrawal: At a } \\
\text { bank, you want to } \\
\text { withdraw RMB } 300 \text {. What } \\
\text { would you say to the } \\
\text { bank teller? }\end{array}$ & $\begin{array}{l}31 \\
(81.58 \%)\end{array}$ & $\begin{array}{lll}\text { 取 } & 300 & \text { (块 钱)。 } \\
\text { Withdraw } & \mathbf{3 0 0} & \text { (MW money). }\end{array}$ & $\begin{array}{l}19 \\
\text { (50.00\%) }\end{array}$ \\
\hline 2 & $\begin{array}{l}\text { Take a cab: You just got } \\
\text { in a taxi. You want to go } \\
\text { to Tsinghua University. } \\
\text { What would you say to } \\
\text { the taxi driver? }\end{array}$ & $\begin{array}{l}24 \\
(97.37 \%)\end{array}$ & $\begin{array}{l}\{\text { 去/到\} (一下) } \\
\text { \{to go/to\} (a bit) } \\
\text { 清华大学。 } \\
\text { Qinghua University. }\end{array}$ & $\begin{array}{l}31 \\
(81.58 \%)\end{array}$ \\
\hline 3 & $\begin{array}{l}\text { Bargain: In a market, you } \\
\text { want to buy a T-shirt but } \\
\text { you think it's a bit } \\
\text { expensive. You want the } \\
\text { vendor to lower the } \\
\text { price. What would you } \\
\text { say to the vendor? }\end{array}$ & $\begin{array}{l}37 \\
(97.37 \%)\end{array}$ & \begin{tabular}{|lll} 
便宜 & 点儿 & (吧/嘛)。 \\
Cheaper & a bit & (PA)
\end{tabular} & $\begin{array}{l}19 \\
(50.00 \%)\end{array}$ \\
\hline
\end{tabular}




\begin{tabular}{|c|c|c|c|c|}
\hline 4 & $\begin{array}{l}\text { Order in restaurant: In a } \\
\text { restaurant, you would } \\
\text { like to order a "Yu xiang } \\
\text { rou si". What would you } \\
\text { say to the waiter/ } \\
\text { waitress? }\end{array}$ & $\begin{array}{l}37 \\
(97.37 \%)\end{array}$ & $\begin{array}{ll}\{\text { 来/要 }\} & \{\text { 个/份 }\} \\
\{\text { Order/need }\} & M W \\
\text { 鱼香肉丝。 } & \\
\text { Yu xiang rou si. }\end{array}$ & $\begin{array}{l}28 \\
(73.68 \%)\end{array}$ \\
\hline 5 & $\begin{array}{l}\text { Leave friend's home: It is } \\
\text { late in the evening. You } \\
\text { are leaving your friend's } \\
\text { home. How would you } \\
\text { say goodbye to your } \\
\text { friend? }\end{array}$ & $\begin{array}{l}34 \\
(89.47 \%)\end{array}$ & $\begin{array}{l}\text { (得/要/先/该) } \\
\text { (have to/need to/first/should) } \\
\text { 走了。 } \\
\text { leave PA }\end{array}$ & $\begin{array}{l}23 \\
(60.53 \%)\end{array}$ \\
\hline 6 & $\begin{array}{l}\text { Try on a hat: In a } \\
\text { department store, you } \\
\text { want to buy a hat but } \\
\text { want to try it on first. } \\
\text { What would you say to } \\
\text { the shop assistant? }\end{array}$ & $\begin{array}{l}31 \\
(81.58 \%)\end{array}$ & $\begin{array}{l}\{\text { 能/可以 }\} \quad\{\text { 试试/试一试/试一下儿\} } \\
\text { \{Can/may }\{\text { try/try one try/try a bit\} } \\
\text { (那个帽子) 吗? } \\
\text { (that hat) QW? }\end{array}$ & $\begin{array}{l}19 \\
(50.00 \%)\end{array}$ \\
\hline 7 & $\begin{array}{l}\text { Send a parcel: At a local } \\
\text { post office, you want to } \\
\text { send a parcel. What } \\
\text { would you say to the } \\
\text { clerk? }\end{array}$ & $\begin{array}{l}27 \\
(71.05 \%)\end{array}$ & $\begin{array}{lll}\text { 我 } & \{\text { 要/想 }\} & \text { 寄 } \\
I & \{\text { want/want } & \text { to mail } \\
(\text { 一个/个/这个) } & \text { 包裏。 } \\
\text { (one } M W / M W / \text { this } & M W \text { ) parcel. }\end{array}$ & $\begin{array}{l}21 \\
(55.26 \%)\end{array}$ \\
\hline 8 & $\begin{array}{l}\text { Favorite dish: In a } \\
\text { restaurant, you and your } \\
\text { friend are ordering food. } \\
\text { You want to know what } \\
\text { your friend likes to order. } \\
\text { What would you say? }\end{array}$ & $\begin{array}{l}37 \\
(97.37)\end{array}$ & $\begin{array}{lll}\text { (你) 想 } & \text { 吃 } & \text { (点儿) } \\
\text { (You) want to } & \text { eat } & \text { (a little) } \\
\{\text { 什么/啥\}? } & & \\
\{\text { what/what }\} & & \end{array}$ & $\begin{array}{l}26 \\
(68.42 \%)\end{array}$ \\
\hline 9 & $\begin{array}{l}\text { Department store: In a } \\
\text { department store, a } \\
\text { shop assistant asks } \\
\text { whether you would like } \\
\text { to buy anything. You do } \\
\text { not intend to buy } \\
\text { anything. How would you } \\
\text { respond? }\end{array}$ & $\begin{array}{l}37 \\
(97.36 \%)\end{array}$ & 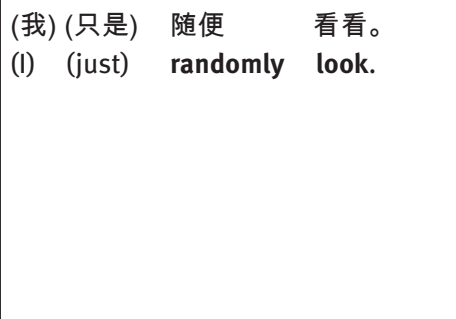 & $\begin{array}{l}22 \\
(57.89 \%)\end{array}$ \\
\hline 10 & $\begin{array}{l}\text { Washroom: In a } \\
\text { restaurant, you want to } \\
\text { go to the restroom but } \\
\text { you don't know where it } \\
\text { is. How would you ask } \\
\text { the waitress? }\end{array}$ & $\begin{array}{l}38 \\
(100.00 \%)\end{array}$ & $\begin{array}{l}\{\text { 卫生间/洗手间/财所 }\} \\
\text { \{restroom/washroom/toilet }\} \\
\text { 在 哪儿 (啊)? } \\
\text { in where } \quad(P A) .\end{array}$ & $\begin{array}{l}24 \\
(63.12 \%)\end{array}$ \\
\hline
\end{tabular}




\begin{tabular}{|c|c|c|c|c|}
\hline 11 & $\begin{array}{l}\text { Where to get off: You are } \\
\text { on a bus. You want to go } \\
\text { to Beijing University but } \\
\text { you don't know where to } \\
\text { get off. How would you } \\
\text { ask the bus conductor? }\end{array}$ & $\begin{array}{l}33 \\
(86.84 \%)\end{array}$ & $\begin{array}{l}\text { 请问 (去/到) } \\
\text { Please ask (to go/to) } \\
\text { 北京大学 在) } \\
\text { Peking University (at) } \\
\text { \{哪(一) 站/哪儿\} } \\
\text { \{which (one) stop/where\} to get off } \\
\text { (车) (啊)? } \\
\text { (bus) (PA)? } \\
\text { (May l ask, where to get off the bus } \\
\text { for Peking University?) }\end{array}$ & $\begin{array}{l}22 \\
(57.89 \%)\end{array}$ \\
\hline 12 & $\begin{array}{l}\text { Wrong phone call: When } \\
\text { you answer your phone, } \\
\text { you found the person on } \\
\text { the other end dialed your } \\
\text { number by mistake. } \\
\text { What would you say? }\end{array}$ & $\begin{array}{l}34 \\
(89.47 \%)\end{array}$ & $\begin{array}{lll}(\text { 您/你) 打 错 } & \text { 了。 } \\
\text { (You) } & \text { dialed wrong } & \text { PA. }\end{array}$ & $\begin{array}{l}22 \\
(57.89 \%)\end{array}$ \\
\hline 13 & $\begin{array}{l}\text { Empty seat: It is very } \\
\text { crowded in the } \\
\text { McDonald's. You see } \\
\text { several people sitting } \\
\text { around a table. However, } \\
\text { there is still one empty } \\
\text { chair next to the table. } \\
\text { You want to sit there. } \\
\text { What would you say to } \\
\text { the people sitting } \\
\text { around that table? }\end{array}$ & $\begin{array}{l}25 \\
(65.79 \%)\end{array}$ & $\begin{array}{lll}\{\text { 这儿/这里/这/这个位置 }\} & \text { 有 } \\
\text { \{here/here/this/this seat }\} & \text { has } \\
\text { 人 } & \text { (坐) } & \text { 吗? } \\
\text { person } & \text { (sit) } & \text { QW? }\end{array}$ & $\begin{array}{l}30 \\
(78.95 \%)\end{array}$ \\
\hline 14 & $\begin{array}{l}\text { Credit card: At the } \\
\text { supermarket checkout, } \\
\text { you want to know } \\
\text { whether the store } \\
\text { accepts credit cards or } \\
\text { not. What would you say } \\
\text { to the cashier? }\end{array}$ & $\begin{array}{l}31 \\
(81.58 \%)\end{array}$ & 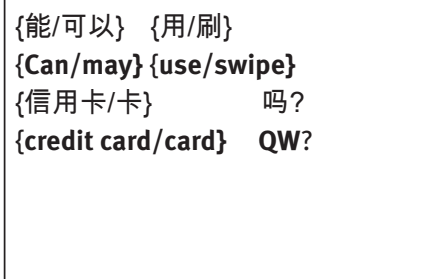 & $\begin{array}{l}32 \\
(84.21 \%)\end{array}$ \\
\hline 15 & $\begin{array}{l}\text { End a phone call: You } \\
\text { and your friend are } \\
\text { talking on the phone. It } \\
\text { seems that you both } \\
\text { have said all you want to } \\
\text { say. How would you end } \\
\text { the phone call? }\end{array}$ & $\begin{array}{l}38 \\
(100.00 \%)\end{array}$ & 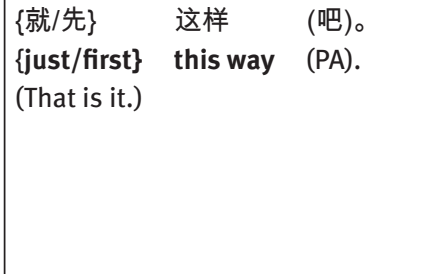 & $\begin{array}{l}23 \\
(60.53 \%)\end{array}$ \\
\hline
\end{tabular}




\begin{tabular}{|c|c|c|c|c|}
\hline 16 & $\begin{array}{l}\text { Ask for price: At a fruit } \\
\text { vendor, you want to } \\
\text { know the price of apples. } \\
\text { What would you say to } \\
\text { the vendor? }\end{array}$ & $\begin{array}{l}38 \\
(100.00 \%)\end{array}$ & $\begin{array}{lll}\text { 苹果 } & \text { 多少 } & \text { 钱 } \\
\text { Apples } & \text { how much } & \text { money } \\
(\text { 一斤 }) & \text { (啊)? } & \\
\text { (one } \mathrm{MW}) & \text { (PA)? }\end{array}$ & $\begin{array}{l}21 \\
(55.26 \%)\end{array}$ \\
\hline 17 & $\begin{array}{l}\text { Cashier: At a department } \\
\text { store, you want to know } \\
\text { where the cashier is. } \\
\text { How would you ask the } \\
\text { shop assistant? }\end{array}$ & \begin{tabular}{|l}
35 \\
$(92.11 \%)$
\end{tabular} & $\begin{array}{l}\{\text { 收银台/款台\} 在 } \\
\{\text { cashier/cashier\} in } \\
\{\text { 哪(儿)/哪里/哪边\}? } \\
\{\text { where/where/where\}? } \\
\text { (Where is the cashier?) }\end{array}$ & $\begin{array}{l}24 \\
(63.16 \%)\end{array}$ \\
\hline 18 & $\begin{array}{l}\text { Ask for direction: You } \\
\text { want to go to Beijing } \\
\text { University but don't } \\
\text { know how to get there. } \\
\text { You want to ask for } \\
\text { directions from a } \\
\text { passer-by. What would } \\
\text { you say to the passer- } \\
\text { by? }\end{array}$ & $\begin{array}{l}35 \\
(92.11 \%)\end{array}$ & $\begin{array}{l}\text { 请问 (去) 北京大学 } \\
\text { Please ask (to) Peking University } \\
\text { 怎么 走 } \quad \text { (啊)? } \\
\text { how to go (PA)? } \\
\text { (May I ask how to go to Peking } \\
\text { University) }\end{array}$ & $\begin{array}{l}24 \\
(63.16 \%)\end{array}$ \\
\hline 19 & $\begin{array}{l}\text { Leave a party early: You } \\
\text { are having dinner with } \\
\text { several of your friends. } \\
\text { Something urgent has } \\
\text { come up and you have to } \\
\text { leave now. What would } \\
\text { you say to your friend? }\end{array}$ & $\begin{array}{l}25 \\
(65.79 \%)\end{array}$ & $\begin{array}{l}\{\text { 先/得/得先\} 走 } \\
\text { \{first/have to/have to first\} leave } \\
\text { 了。 } \\
\text { PA. } \\
\text { (have to leave first.) }\end{array}$ & $\begin{array}{l}25 \\
(65.79 \%)\end{array}$ \\
\hline 20 & $\begin{array}{l}\text { Late for a meeting: You } \\
\text { are a few minutes late } \\
\text { for a meeting with your } \\
\text { friend. You see your } \\
\text { friend waiting for you. } \\
\text { What would you say to } \\
\text { your friend? }\end{array}$ & $\begin{array}{l}28 \\
(73.68 \%)\end{array}$ & $\begin{array}{l}\text { 不好意思 (我) } \\
\text { Sorry (I) } \\
\{\text { 来晚了/迟到了\}。 } \\
\text { \{arrive late/was late\}. }\end{array}$ & $\begin{array}{l}21 \\
(55.26 \%)\end{array}$ \\
\hline 21 & $\begin{array}{l}\text { Call Professor Wang: You } \\
\text { have never met Professor } \\
\text { Wang before. You are } \\
\text { now calling him for } \\
\text { something. You hear } \\
\text { someone pick up the } \\
\text { phone and say "Wei". } \\
\text { What would you say? }\end{array}$ & \begin{tabular}{|l}
33 \\
$(86.84 \%)$
\end{tabular} & $\begin{array}{l}\text { 请问 (您) 是 } \\
\text { Please ask (you) are } \\
\text { 王老师 吗? } \\
\text { Wang Teacher QW? } \\
\text { (May I ask if you are Teacher Wang?) }\end{array}$ & \begin{tabular}{|l}
24 \\
$(63.16 \%)$
\end{tabular} \\
\hline
\end{tabular}




\begin{tabular}{|c|c|c|c|c|c|}
\hline 22 & $\begin{array}{l}\text { Pass a crowd: You are } \\
\text { walking in the street. A } \\
\text { person is standing in } \\
\text { your way, but you want to } \\
\text { pass by. What would you } \\
\text { say to that person? }\end{array}$ & $\begin{array}{l}34 \\
(89.47)\end{array}$ & $\begin{array}{l}\{\text { 麻烦/请 }\} \\
\text { \{Trouble/please } \\
\{\text { 让一下/让一让/过一下 } \\
\text { \{yield a bit/yield a yield }\end{array}$ & /pass a bit\}. & $\begin{array}{l}23 \\
(60.53 \%)\end{array}$ \\
\hline 23 & $\begin{array}{l}\text { Bus service: A bus is } \\
\text { coming to a bus stop } \\
\text { where you are waiting. } \\
\text { You want to go to Beijing } \\
\text { University but you are } \\
\text { not sure whether the bus } \\
\text { stops there. How would } \\
\text { you ask the bus driver? }\end{array}$ & $\begin{array}{l}35 \\
(92.11)\end{array}$ & $\begin{array}{l}\text { 到 北大 } \\
\text { to Peking University }\end{array}$ & $\begin{array}{l}\text { 吗? } \\
\text { QW? }\end{array}$ & $\begin{array}{l}31 \\
(81.58 \%)\end{array}$ \\
\hline 24 & $\begin{array}{l}\text { Wrap up leftovers: In a } \\
\text { restaurant, you want to } \\
\text { take the leftovers with } \\
\text { you. What would you say } \\
\text { to the waiter/waitress? }\end{array}$ & $\begin{array}{l}36 \\
(94.74)\end{array}$ & $\begin{array}{l}\text { 打包。 } \\
\text { wrap up. }\end{array}$ & & $\begin{array}{l}21 \\
(55.26 \%)\end{array}$ \\
\hline
\end{tabular}




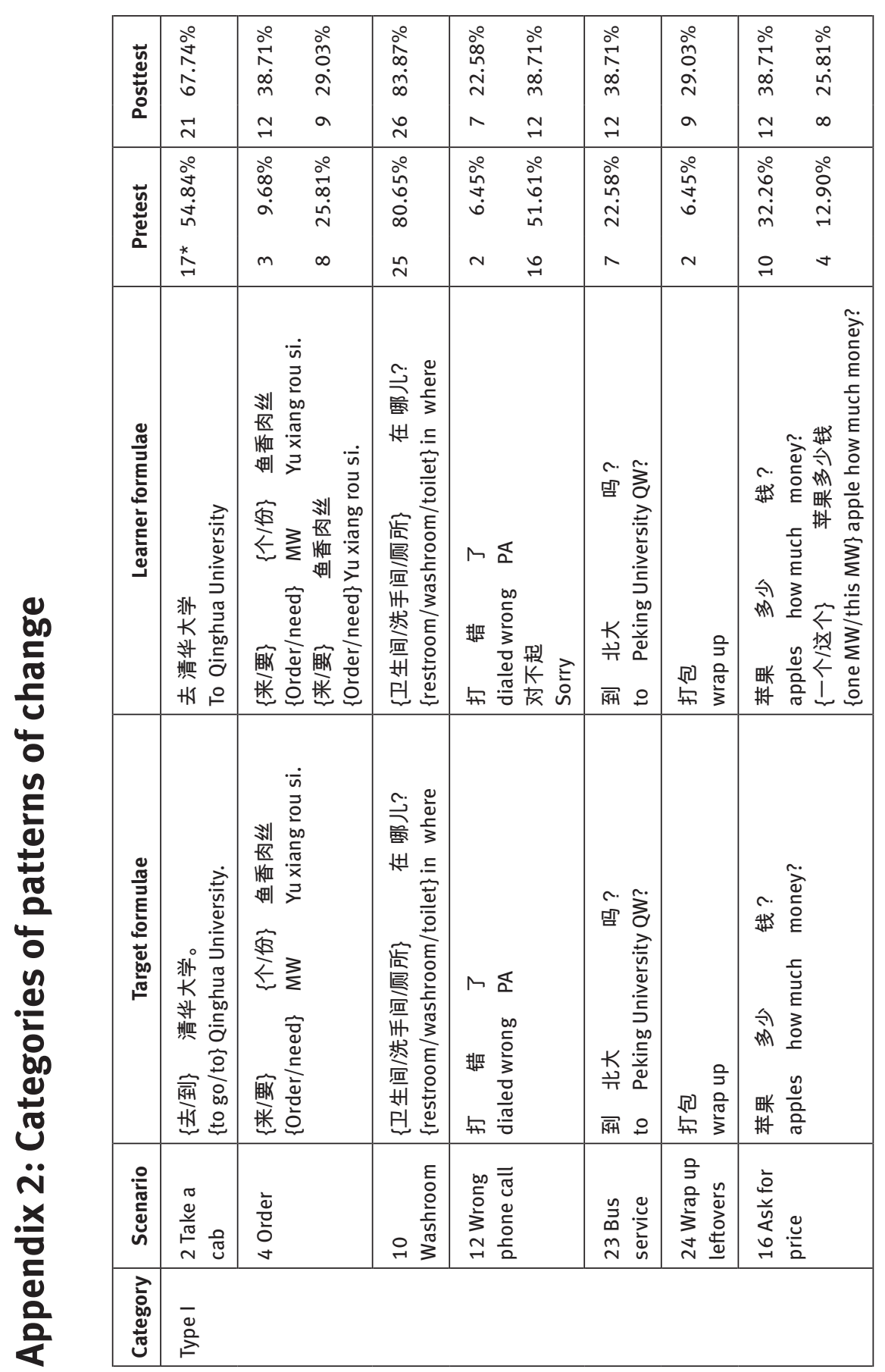




\begin{tabular}{|c|c|c|c|c|}
\hline $\begin{array}{l}\stackrel{\circ}{\circ} \\
\stackrel{\circ}{\infty} \\
\stackrel{\infty}{\infty} \\
\infty \\
\stackrel{\sim}{1}\end{array}$ & $\begin{array}{l}\circ \circ \\
\stackrel{\circ}{b} \\
\dot{1} \\
i n \\
0 \\
\end{array}$ & 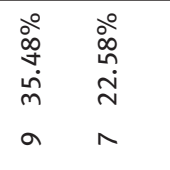 & 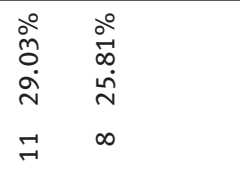 & $\begin{array}{l}\stackrel{\circ}{\circ} \\
\vec{b} \\
\stackrel{-1}{n} \\
0 \\
-1\end{array}$ \\
\hline 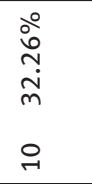 & 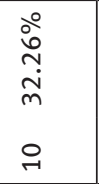 & $\begin{array}{ll}\stackrel{\circ}{\circ} & \stackrel{\circ}{\circ} \\
\stackrel{i}{N} & \stackrel{0}{6} \\
\sim & N\end{array}$ & $\begin{array}{ll}\stackrel{\circ}{\circ} & \stackrel{\circ}{\infty} \\
\stackrel{0}{0} & \stackrel{\sim}{N} \\
\stackrel{N}{N} & \\
\wedge & \wedge\end{array}$ & 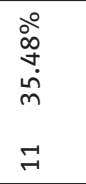 \\
\hline 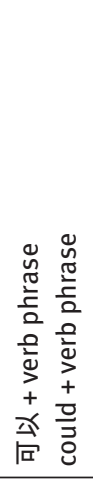 & 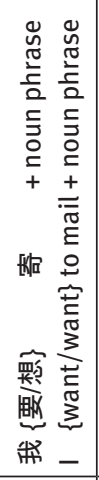 & 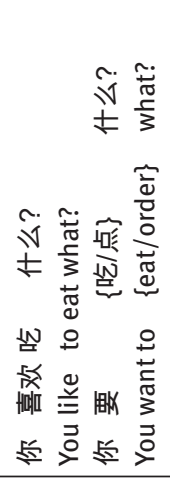 & 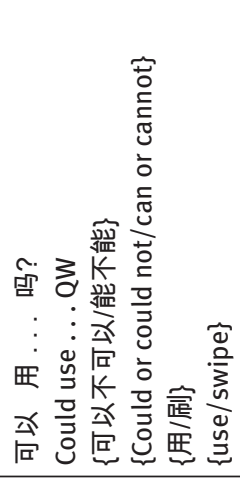 & 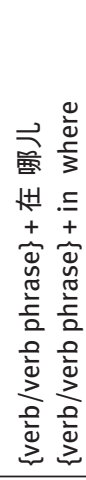 \\
\hline 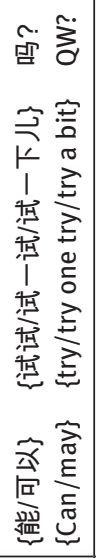 & 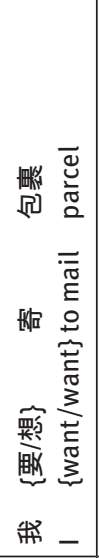 & 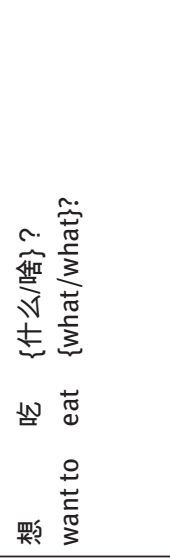 & 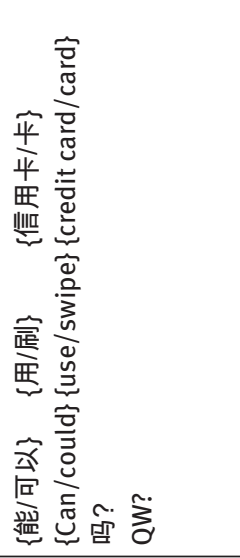 & 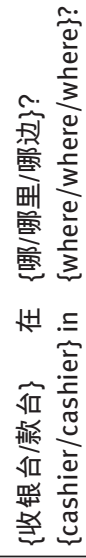 \\
\hline 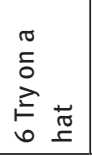 & 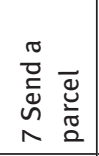 & 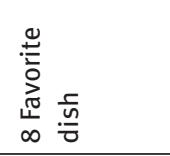 & 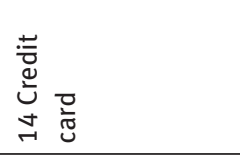 & 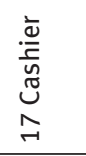 \\
\hline $\begin{array}{l}\overline{\bar{o}} \\
\stackrel{2}{\gtrless}\end{array}$ & & \multicolumn{3}{|l|}{$\stackrel{\bar{\Xi}}{\stackrel{2}{\gtrless}}$} \\
\hline
\end{tabular}




\begin{tabular}{|c|c|c|c|}
\hline $\begin{array}{ll}\stackrel{0}{0} & \stackrel{0}{m} \\
\text { o } & \infty \\
\stackrel{n}{N} & \stackrel{N}{N} \\
a & N\end{array}$ & 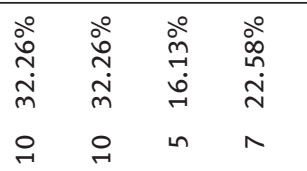 & $\begin{array}{l}0 \\
\circ \\
\overrightarrow{0} \\
i \\
i n \\
0 \\
r\end{array}$ & 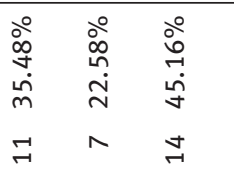 \\
\hline 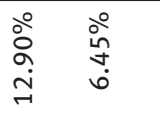 & 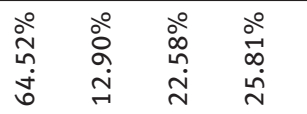 & $\begin{array}{l}\stackrel{\circ}{\grave{m}} \\
\stackrel{0}{0}\end{array}$ & 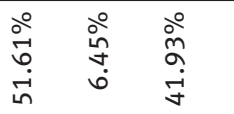 \\
\hline$\checkmark \quad N$ & $\stackrel{N}{ } \wedge$ & $a$ & $\stackrel{\sim}{\sim} \quad \sim \quad \stackrel{m}{\sim}$ \\
\hline 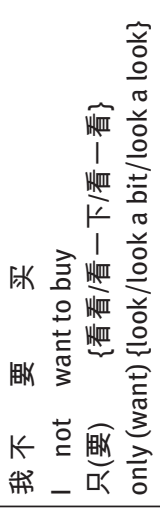 & 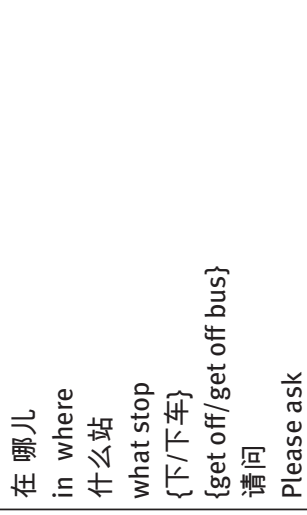 & 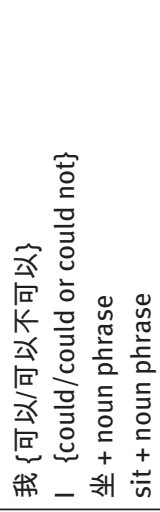 & 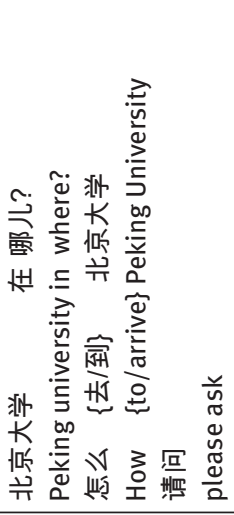 \\
\hline 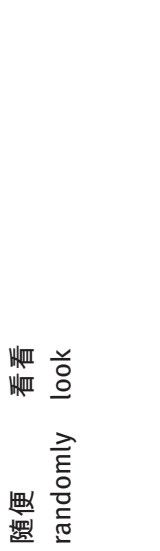 & 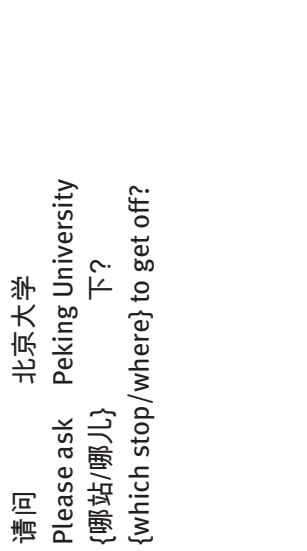 & 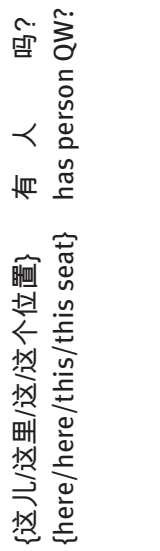 & 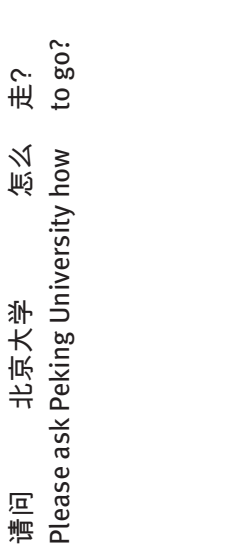 \\
\hline 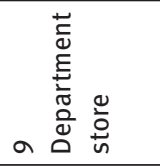 & 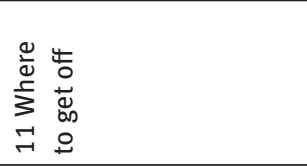 & 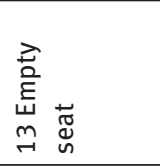 & 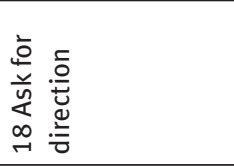 \\
\hline 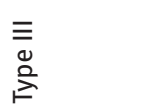 & & & 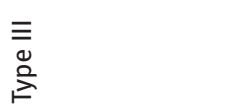 \\
\hline
\end{tabular}




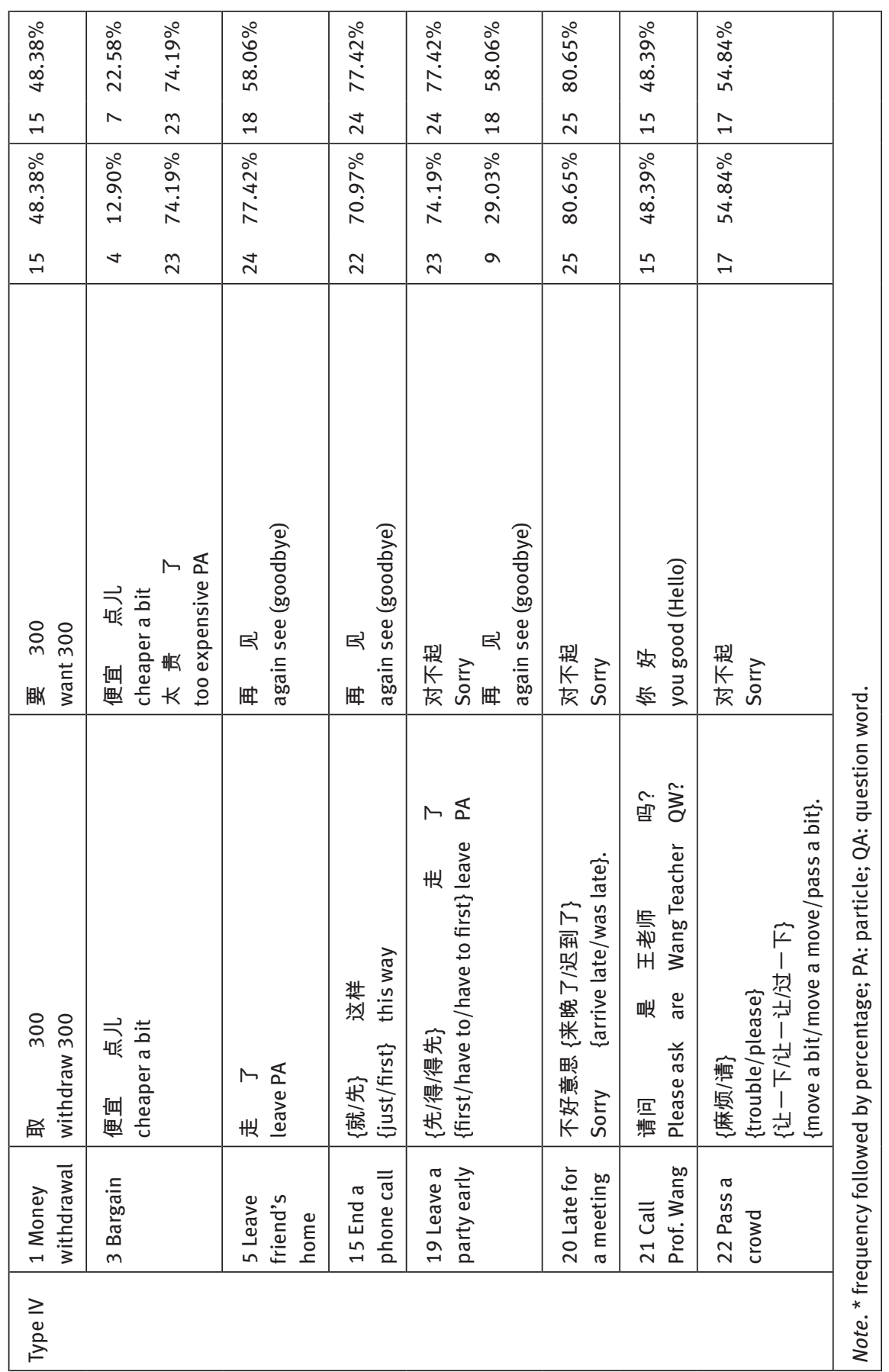

